\title{
Reaction of soybean cultivars to the root-knot nematode Meloidogyne javanica
}

\section{Reação de cultivares de soja ao nematoide de galha Meloidogyne javanica}

\author{
Renato Andrade TEIXEIRA ${ }^{1}$; Kássia Aparecida Garcia BARBOSA²; Mara Rúbia da ROCHA ${ }^{3}$
} ${ }^{1}$ Autor para correspondência, Doutor, Universidade Federal de Goiás, Escola de Agronomia, Laboratório de Nematologia.
Rodovia Goiânia-Nova Veneza, km 0, CP 131, CEP 74690-900, Campus Samambaia. Goiânia, Goiás. E-mail:
renato.ateixeira@terra.com.br
${ }^{2}$ Doutora, Fundação de Ensino Superior de Goiatuba. E-mail: kassiabarbosa@yahoo.com.br
${ }^{3}$ Doutora, Universidade Federal de Goiás, Escola de Agronomia, Laboratório de Nematologia. E-mail:
darochamarabia@gmail.com

Recebido em: 18-02-2015; Aceito em: 24-11-2016

\begin{abstract}
Meloidogyne javanica is one of the main nematodes that attack soybean crops and although genetic resistance is the ideal control measure, few cultivars are described as resistant among the innumerous cultivars recommended for the Central Region of Brazil. In this context, we aimed to evaluate the reaction of 29 soybean cultivars to M. javanica. Two experiments were conducted under greenhouse conditions in a completely randomized design with six replications. The plants were inoculated with a suspension of 2000 eggs and J2 of $M$. javanica and the evaluations occurred sixty days after the inoculation (DAl), determining the nematode population density and the reproduction factor. Based on the results from these two experiments we conducted another experiment selecting four soybean cultivars, one moderately resistant and three with an unknown behavior. These cultivars were inoculated with different concentrations of $M$. javanica inoculum. The experiment was conducted in a completely randomized design in a $4 \times 4$ factorial scheme with twelve replications. Evaluations were carried out at $10 \mathrm{DAl}$ by observing the number of $\mathrm{J} 2$ and $\mathrm{J} 3 /$ root system. At 45 DAl the nematode population density in the roots was evaluated. Of the soybean cultivars tested, none behaved as resistant. However, the cultivars UFU Carajás and BRSGO Paraíso presented less M. javanica development in the roots compared to the P98Y70 and NS 7478 and as the inoculum pressure was increased, the penetration and development of the nematode in the roots increased.
\end{abstract}

Additional keywords: inoculum concentration; penetration; resistance; root-knot nematodes.

\begin{abstract}
Resumo
Meloidogyne javanica é um dos principais nematoides que atacam a cultura da soja e, embora a resistência genética seja a medida de controle ideal, existem poucas cultivares descritas como resistentes dentre as inúmeras cultivares recomendadas para a Região Central do Brasil. Neste contexto, objetivou-se avaliar a reação de 29 cultivares de soja ao nematoide $M$. javanica. Foram conduzidos dois experimentos em condições de casa de vegetação, instalados em delineamento inteiramente casualizado, com seis repetições. As plantas foram inoculadas com uma suspensão de 2.000 ovos e J2 de M. javanica, e as avaliações ocorreram sessenta dias após a inoculação (DAl), determinando-se a densidade populacional do nematoide e o fator de reprodução. A partir dos resultados destes experimentos, foram selecionadas quatro cultivares de soja, sendo uma moderadamente resistente e três com comportamento desconhecido, e foram inoculadas com diferentes concentrações de inóculo de $M$. javanica. Este experimento foi conduzido em delineamento inteiramente casualizado, em esquema fatorial $4 \times 4$, com doze repetições. Avaliações foram realizadas aos $10 \mathrm{DAl}$, observando-se o número de J2 e $\mathrm{J} 3 /$ sistema radicular. Aos $45 \mathrm{DAl}$, avaliou-se a densidade populacional do nematoide nas raízes. Entre as cultivares de soja testadas, nenhuma se comportou como resistente. Porém as cultivares UFU Carajás e BRSGO Paraíso apresentaram menor desenvolvimento de $M$. javanica nas raízes, em comparação com as cultivares P98Y70 e NS 7476, e à medida que aumentou a pressão de inóculo, aumentou a penetração e o desenvolvimento do nematoide nas raízes.
\end{abstract}

Palavras-chave adicionais: concentração de inóculo; nematoide de galhas; penetração; resistência.

\section{Introduction}

Global soybean production in the 2013/2014 harvest increased by 45,648 thousand tons in relation to the 2006/07 harvest, and Brazil, being the second biggest global producer, contributed with an increase of 26,000 thousand tons (Agrianual, 2014). By pressing soy grains, bran and raw oil is obtained, as well as derivatives such as degummed oil, margarines, and fats. The large production capacity for bran and oils, 
which are used for human and animal consumption, means that soybean is the most important crop in Brazilian agribusiness (Costa, 2005). However, crop yield can be threatened by the attack of pests and diseases, including nematodes.

Various plant nematode species occur in soybean plantations in Brazil, however only five currently cause generalized losses: Pratylenchus brachyurus, Heterodera glycines, Rotylenchulus reniformis, Meloidogyne javanica, and Meloidogyne incognita (Inomoto \& Silva, 2011). Root-knot nematodes of the genus Meloidogyne are obligatory parasites and constitute the main group of nematodes of economic importance, as their species are widely spread and attack almost all crops, causing considerable losses (Ferraz \& Mendes, 1992).

The genus Meloidogyne includes more than 80 species, such as $M$. arenaria, $M$. hapla, $M$, coffeicola, $M$. exigua, and $M$. graminicola, but the main species for soybean crops are $M$. javanica and $M$. incognita (Ferraz, 2001; Miranda et al., 2011). Among the various species of Meloidogyne, the most common root-knot forming species of nematode in soybean crops in Brazil is Meloidogyne javanica, which can cause losses of $10 \%$ to $40 \%$, especially in regions with sandy or intermediate-sandy soil (with less than $25 \%$ clay) (Inomoto \& Silva, 2011).

In soybean crops slow and unbalanced growth among plants can be observed as symptoms of Meloidogyne sp. attack often with the stunting of plants in the central part of fields. Symptoms of nutritional imbalance are common and most often expressed via chlorosis on leaves, which can vary from light to intense due to low photosynthesis rates (Ferraz, 2001). The most characteristic symptoms of these nematodes appear in the root system. Due to nematode penetration devitalization occurs in the root tips, which stops growth and can cause an excessive formation of short lateral roots as well as the formation of root-knots (Ferraz \& Mendes, 1992). Root-knots involve root thickenings of varied sizes that house one to dozens of nematode females (Inomoto \& Silva, 2011). The size of the root-knot depends on the species of Meloidogyne, on the host plant, and on the growth conditions, and in some cases the formation of root-knots may not occur, even with nematode infestation (Ferraz \& Mendes, 1992; Moura, 1997).

Nematodes of the Meloidogyne genus have developed an elaborate parasitism strategy in which root cells of host plants are turned into differentiated nourishing tissue, able to provide a regular supply of necessary nutrients for total nematode development and full reproduction. This process begins after penetration by second stage juveniles (J2), which begin to feed and, via the stylet, inject esophageal secretions into the cytoplasm of a small group of cells located in the vascular cylinder or adjacent area. These cells show morphological (hypertrophies) and physiological alterations, with cytoplasm of a dense, course nature associated with successive divisions of the nuclei, not accompanied by divisions in the cell itself, and going on to be called giant or nourishing cells. These nematodes become sedentary, as a disintegration of muscular cells and rapid increase in body length occur (Ferraz \& Mendes, 1992; Moura, 1996; Ferraz, 2001). Due to these characteristics, the search for Meloidogyne sp. resistant cultivars is generally more promising.

Genetic resistance is one of the main methods for nematode control. This can be defined as some factor or various factors in the plants that will inhibit root penetration and the development or reproduction of the nematode. Giant cells in resistant cultivars can be malformed resulting in little or slower nematode development, since it feeds on these cells and thus ceases to produce or produces fewer eggs. Resistance can also derive from factors that are present even before nematodes enter into the roots, thus adversely affecting their penetration (Moritz et al., 2008). After nematodes penetrate the root, resistance mechanisms can act, interrupting the nematode cycle (Carneiro et al., 2005). One of the resistance mechanisms can be the accumulation of phytoalexins, which coincide with a hypersensitive reaction, working as nematostatic phytoalexins and drastically affecting nematode function and impeding their development (Faria et al., 2003).

The use of crop rotation or definitive planting with cultivars that are resistant or tolerant to Meloidogyne have been an important tool for reducing the damage caused by this nematode (Ferraz, 2001). But in some cases genetic resistance does not exist, it is low, or a breakdown in resistance occurs due to the large genetic variability existing among the pathogen isolates. Thus, the search to identify sources of resistance to root-knot nematodes is constant (Yorinori \& Kiihl, 2001; Ferraz, 2006).

The initial nematode population density can interfere in development, causing a reduction in the soybean growth. Rocha et al. (2008) evaluated soybean cultivars twenty days after inoculation with inoculum concentrations of $M$. javanica varying from 0 to 300 eggs/plant. They observed that the weigh of plant root system was the same at any of the inoculum levels but, greater than in the non-inoculated control, which may be attributed to the low inoculum levels used. However, Asmus \& Ferraz (2001) found that greater inoculum levels affect plant development. By using increasing inoculum amounts varying from 1200 to 97200 eggs of $M$. javanica they observed reductions in the grain production and shoots total dry mass.

Although there are several cultivars resistant to $M$. incognita out of the innumerous ones recommended for the central region of Brazil (Embrapa, 2011) few are described as resistant to $M$. javanica. The reaction of a number of them to this nematode has 
not been described. Thus, this study had the purpose to evaluate the reproductive capacity of $M$. javanica in soybean cultivars indicated for the central region of Brazil and to evaluate the penetration and development of this nematode in soybean cultivars under different inoculum concentrations.

\section{Material and methods}

Three experiments were conducted under greenhouse conditions in Goiania, Goiás, Brazil (16 $35^{\prime} 47^{\prime \prime} \mathrm{S}$ and 49'16'47" W and altitude of $728 \mathrm{~m}$ ). Two experiments aimed to evaluate the reaction of 29 soybean cultivars to Meloidogyne javanica. The third experiment was to evaluate the penetration and development of $M$. javanica in four soybean cultivars inoculated with four different inoculum concentrations. The first two experiments were conducted in a completely randomized design with six replications. The third experiment was conducted in a completely randomized design, in a $4 \times 4$ factorial scheme, with twelve replications.

\section{Reaction of soybean cultivars to $M$. javanica.}

A total of 29 soybean cultivars were used, 26 cultivars with no resistance or susceptibility reaction described (Embrapa, 2011). Moreover, one cultivar described as moderately resistant (BRSGO Paraíso) and two susceptible cultivars (BRSGO Raíssa and BRSGO Santa Cruz) were used as standards for comparison.

Four seeds were sown in plastic cups with a $400 \mathrm{~mL}$ capacity on December 7, 2011 (first experiment) and January 9, 2012 (second experiment). Substrate previously sterilized containing a mixture of soil and sand in a 1:1 proportion was used. After twelve days, the plots were thinned, leaving one plant per plot, which was inoculated with a water solution containing 2000 eggs and J2 of M. javanica.

During the period of experiment plants were watered daily, maintaining an adequate level of soil humidity for plant growth. The maximum and minimum atmosphere temperatures were recorded.

After sixty days, the plants were removed from the pots. Roots were washed and weighed on digital scales. The Coolen \& D'Herde (1972) technique was used to extract the nematodes from the roots. Nematodes were counted under an optical microscope (100x magnification) using a Peters slide. The nematodes were preserved in Golden $X$ solution, as in Hooper (1970).

After quantifying the nematodes, the reproduction factor (RF) was obtained by dividing the final population by the initial population, as described by Oostenbrink (1966). The Moura \& Régis (1987) criteria was used to classify the reaction of each cultivar. In this rating the cultivar that presents the highest $R F$ is used as a susceptibility standard. Then, this is compared with each one of the other cultivars, calcu- lating the percentage reduction in the RF. Each cultivar is classified into: highly susceptible ( 0 to $25 \%$ reduction in $\mathrm{RF}$ ), susceptible ( 26 to $50 \%$ reduction in $\mathrm{RF}$ ), little resistant (51 to $75 \%$ reduction in $\mathrm{RF}$ ), moderately resistant (76 to $95 \%$ reduction in $\mathrm{RF}$ ), resistant (96 to $99 \%$ reduction in $\mathrm{RF})$, or highly resistant $(100 \%$ reduction in RF)

The population density (eggs and J2/10 $\mathrm{g}$ of root) data were transformed into $\sqrt{\mathrm{x}}$ for the analysis of variance for the first and second experiments individually. Then, the Hartley test (Ramalho et al., 2000) was carried out to verify the homogeneity of variance between the two experiments. With homogeneity occurring, joint analysis of the experiments was carried out. The averages from the experiments were compared using the Scott-Knott test with a $5 \%$ probability.

\section{M. javanica penetration and development in soybean cultivars under different inoculum concentrations.}

In order to carry out this experiment, four soybean cultivars were selected, using the BRSGO Paraíso cultivar as the standard, as its reaction to M. javanica has already been described as moderately resistant (Embrapa, 2011). The other cultivars had no described reaction.

The seeds of the selected cultivars were sown (four per pot) on July 12, 2012, in $400 \mathrm{~mL}$ plastic cups containing substrate with a 1:1 proportion of soil and sand, previously sterilized. After thirteen days plants were thinned leaving one plant per plot. Inoculation was performed with a suspension of eggs and $\mathrm{J} 2$ of $M$. javanica according to the treatment $(300,600$, 1200 , and 2400 de M. javanica eggs/plant).

Ten days after inoculation six replications of each treatment were removed to evaluate nematode penetration. After determining the root fresh weigh roots were stained with acid fuchsine using the technique described by Byrd et al. (1983). Stained roots were taken to the stereomicroscope to quantify the nematode penetration in the roots and identify the nematode life stage.

At 45 days after the inoculation the plants from the six remaining replications were removed from the pots and taken to the laboratory. Roots were washed and weighed then processed by the Coolen \& D'Herde (1972) technique in order to extract the nematodes quantifying the number of eggs and J2 per root system. With these final population data, the reproduction factor (RF) was determined using the ratio between the final population and the initial population (Oostenbrink, 1966). Using the RF averages, the classification was carried out in accordance with Moura \& Régis (1987).

The data were transformed into $\sqrt{(x+0.5)}$ in order to run the statistical analysis. Analysis of variance were carried out and when differences were found among the cultivars the Tukey test was applied (5\% probability) to compare the means. When there was significant difference among the inoculum concentrations regression analysis was carried out. Statistical analysis were performed using the Sisvar statistical application (Ferreira, 2011). 


\section{Results and discussions}

\section{Reaction of soybean cultivars to $M$. javanica.}

The Hartley test (Ramalho et al., 2000) revealed significant differences between the two experiment variances, indicating that they should be analyzed separately. By observing the nematode population density, it is noted that high values occurred in both experiments and this resulted in quite high RFs (Table 1). In the first experiment the population densities were much higher than in experiment 2 and the Scott Knott test divided the cultivars into three groups.
In the second experiment cultivars were separated into two groups.

The RF was higher or equal to 1,0 for all cultivars in both experiments and according to the Oostenbrink (1966) criteria the cultivars were classified as susceptible. However, it is noted that differences occurred between the FR's. In the first experiment the formation of three groups occurred, with the CD 237 RR, BRSGO 8860 RR, and BRSGO Graciosa cultivars being the most susceptible. In the second experiment, only two groups were formed considering the RF (Table 2).

Table 1 - Population density (PD), reproduction factor (RF), \% of inhibition compared with the susceptibility standard, and classification (C) of soybean cultivars inoculated with M. javanica.

\begin{tabular}{|c|c|c|c|c|c|c|c|c|}
\hline \multirow[b]{2}{*}{ Cultivar } & \multicolumn{4}{|c|}{ Experiment $1^{1}$} & \multicolumn{4}{|c|}{ Experiment $2^{1}$} \\
\hline & $\begin{array}{l}\mathrm{PD}^{*} \text { (eggs and } \\
\mathrm{J} 2 / 10 \mathrm{~g} \text { of root) }\end{array}$ & $\mathrm{RF}^{\star}$ & $\%$ inhibition & $\mathrm{C}^{2}$ & $\begin{array}{l}\mathrm{PD}^{*} \text { (eggs and } \\
\mathrm{J} 2 / 10 \mathrm{~g} \text { of root) }\end{array}$ & $\mathrm{RF}^{*}$ & $\%$ inhibition & $\mathrm{C}^{2}$ \\
\hline 98N82 & $39,858 a$ & $3.9 a$ & 77 & MR & $54,097 \mathrm{~b}$ & $3.3 \mathrm{a}$ & 57 & LR \\
\hline BRSGO Paraíso (MR) ${ }^{3}$ & $42,013 a$ & $4.7 a$ & 72 & LR & $33,595 a$ & $3.7 \mathrm{a}$ & 52 & LR \\
\hline TMG 1179 RR & $46,370 a$ & $4.0 \mathrm{a}$ & 76 & MR & $62,713 b$ & $7.1 \mathrm{~b}$ & 9 & $\mathrm{HS}$ \\
\hline BRSGO Raissa $(\mathrm{S})^{3}$ & $52,855 a$ & $6.8 a$ & 59 & LR & $44,994 b$ & $2.2 \mathrm{a}$ & 71 & LR \\
\hline UFU Carajás & $57,111 \mathrm{a}$ & $7.5 \mathrm{a}$ & 55 & LR & $26,698 a$ & $3.7 \mathrm{a}$ & 52 & LR \\
\hline TMG 1288 RR & $57,849 a$ & $5.3 a$ & 68 & LR & $24,530 a$ & $1.7 \mathrm{a}$ & 78 & MR \\
\hline BRS 206 & $57,896 a$ & $7.9 a$ & 52 & LR & $44,053 b$ & $4.7 \mathrm{~b}$ & 40 & S \\
\hline NA $7620 \mathrm{RR}$ & $59,870 a$ & $4.9 a$ & 71 & LR & $36,366 a$ & $3.7 \mathrm{a}$ & 52 & LR \\
\hline NS 8270 & $59,984 a$ & $6.7 \mathrm{a}$ & 60 & LR & $17,004 a$ & $1.0 \mathrm{a}$ & 87 & MR \\
\hline UFU Guarani & $60,692 a$ & $7.6 a$ & 54 & LR & $75,370 b$ & $6.5 \mathrm{~b}$ & 16 & HS \\
\hline UFU Xavante & $70,828 b$ & $5.6 a$ & 66 & LR & $47,820 b$ & $5.5 \mathrm{~b}$ & 29 & $\mathrm{~S}$ \\
\hline P98Y70 & $74,843 b$ & $4.7 \mathrm{a}$ & 72 & LR & $74,748 b$ & $5.1 \mathrm{~b}$ & 35 & $S$ \\
\hline BRSGO Santa Cruz(S) ${ }^{3}$ & $81,267 b$ & $9.1 b$ & 46 & $\mathrm{~S}$ & $49,391 b$ & $4.6 \mathrm{~b}$ & 41 & $\mathrm{~S}$ \\
\hline AN 8500 & $84,891 b$ & $6.2 \mathrm{a}$ & 63 & LR & $52,745 b$ & $5.1 \mathrm{~b}$ & 34 & S \\
\hline UFUS Riqueza & $84,960 b$ & $8.2 a$ & 51 & LR & $61,244 b$ & $6.6 \mathrm{~b}$ & 15 & HS \\
\hline NS 7490 & $86,962 b$ & $10.0 \mathrm{~b}$ & 40 & $\mathrm{~S}$ & $52,783 b$ & $5.5 \mathrm{~b}$ & 30 & $S$ \\
\hline NS 7476 & $90,857 b$ & $9.4 \mathrm{~b}$ & 43 & $\mathrm{~S}$ & $47,802 b$ & $4.6 \mathrm{~b}$ & 40 & $\mathrm{~S}$ \\
\hline UFU Milionária & $99,453 c$ & $10.9 b$ & 34 & $\mathrm{~S}$ & $46,703 b$ & $4.4 \mathrm{~b}$ & 43 & $S$ \\
\hline AN 8843 & $101,214 c$ & $10.5 b$ & 37 & S & $43,650 b$ & $5.0 \mathrm{~b}$ & 36 & $S$ \\
\hline P98Y51 & $101,991 \mathrm{c}$ & $9.8 \mathrm{~b}$ & 41 & $\mathrm{~S}$ & $55,296 b$ & $3.9 \mathrm{a}$ & 50 & $\mathrm{~S}$ \\
\hline NA 7255 RR & $108,633 c$ & $9.6 \mathrm{~b}$ & 42 & $S$ & $64,547 b$ & $7.8 \mathrm{~b}$ & Standard & $\mathrm{HS}$ \\
\hline UFUS Impacta & $115,205 c$ & $12.2 b$ & 27 & $\mathrm{~S}$ & $48,700 b$ & $5.7 \mathrm{~b}$ & 26 & $\mathrm{~S}$ \\
\hline NA 8015 RR & $126,191 c$ & $12.3 b$ & 27 & $\mathrm{~S}$ & $43,682 b$ & $2.6 \mathrm{a}$ & 66 & LR \\
\hline BRSGO 8860RR & $138,008 d$ & $16.1 \mathrm{c}$ & 3 & HS & $32,935 a$ & $2.2 \mathrm{a}$ & 72 & LR \\
\hline NA 7337 & $143,154 d$ & $10.5 b$ & 37 & $\mathrm{~S}$ & $58,202 b$ & $4.6 \mathrm{~b}$ & 40 & $\mathrm{~S}$ \\
\hline TMG $1181 \mathrm{RR}$ & $144,705 d$ & $12.0 \mathrm{~b}$ & 28 & $S$ & $45,832 b$ & $3.0 \mathrm{a}$ & 61 & LR \\
\hline CD 237 RR & $157,043 d$ & $15.4 c$ & 8 & HS & $26,652 a$ & $2.6 \mathrm{a}$ & 66 & LR \\
\hline A 7002 & $160,200 d$ & $9.3 b$ & 44 & $\mathrm{~S}$ & $60,987 b$ & $4.3 \mathrm{~b}$ & 44 & $\mathrm{~S}$ \\
\hline BRSGO Graciosa & $186,580 d$ & $16.7 c$ & Standard & $\mathrm{HS}$ & $63,113 b$ & $4.7 \mathrm{~b}$ & 40 & $S$ \\
\hline Average & 92,809 & 8.9 & & & 48,146 & 4.4 & & \\
\hline CV (\%) & 19.92 & 56.89 & & & 20.46 & 60.30 & & \\
\hline
\end{tabular}

1. Means followed by the same letter in the columns do not differ from each other (Scott Knott, $5 \%$ probability).

2. Classification proposed by Moura \& Régis (1987) in which HS= Highly susceptible, $\mathrm{S}=$ Susceptible, LR= Low resistance, $\mathrm{MR}=$ Moderately resistant.

3. Classification described by Embrapa (2011), where MR= Moderately Resistant, $\mathrm{S}=$ Susceptible.

* - Values transformed into $\sqrt{x}$ for the statistical analysis.

No cultivar was classified as resistant or highly resistant according to Moura \& Régis (1987) criteria (Table 1). It was observed that in both experiments that the cultivars BRSGO Paraíso and BRSGO Raissa, classified as moderately resistant and susceptible to $M$. javanica, respectively, by Embrapa (2011), were rated as of low resistance according to the Moura \& Régis (1987) criteria. The cultivar BRSGO Santa Cruz, another susceptibility standard, was rated as susceptible in both experiments, thus corroborating with the Embrapa (2011) classification. 
As the Moura \& Régis (1987) criteria uses the cultivar that presented the highest nematode reproduction factor as the susceptibility standard, it was noted that in the first experiment the susceptibility standard was the cultivar BRSGO Graciosa and in the second experiment the susceptibility standard was the cultivar NA 7255 RR.

In the first experiment it is observed that fourteen cultivars were rated as of low resistance or moderately resistant, while the other fifteen cultivars were rated as susceptible or highly susceptible. The cultivars BRSGO Graciosa, BRSGO 8860 RR, and CD 237 RR presented the highest reproduction factors and were rated as highly susceptible. The cultivars TMG 1179 $\mathrm{RR}$ and $98 \mathrm{~N} 82$ were the only ones rated as moderately resistant because they presented the highest $R F$ inhibition rates.

In the second experiment it is observed that eighteen cultivars were rated as susceptible or highly susceptible and nine cultivars were rated as of low resistance. Only TMG 1288 RR and NS 8270 were rated as moderately resistant, as they presented a reduction in $\mathrm{RF}$, varying from $76 \%$ to $95 \%$, in relation to the highly susceptible standard (NA 7255 RR), in accordance with the Moura \& Régis (1987) criteria.

Based on the results obtained here, it cannot be affirmed whether there is resistance to $M$. javanica among the cultivars tested, since the best results, according to the Moura \& Régis (1987) criteria, were for the cultivars 98N82 and TMG 1179RR in the first experiment and TMG 1288RR and NS8270 in the second experiment. It can be observed that the best cultivars did not coincide in the two experiments. However, they had moderately resistant behavior. Nonetheless, it can be recommended that in infested areas the cultivars that presented lower RFs should be preferred by the growers.

The variation in the isolate aggressiveness is a factor than can lead to differences in the cultivar reaction as occurred in Tihohod \& Ferraz (1986). These authors inoculated soybean cultivars with two different isolates of $M$. javanica and observed differences in the cultivars' responses. In this study it cannot be affirmed that this was the case because the inoculum was obtained from the same source and uniformly multiplied in plants of tomato 'Santa Cruz'.

According to Mendes \& Rodriguez (2000), the adoption of different methods for rating cultivars may also generate contradictory results. Dias et al. (2010) rated the soybean cultivar BRSGO Paraíso (FR =6.5) as tolerant to M. enterolobii (Yang \& Eisenback, 1983) using the Canto-Saénz classification, proposed by Sasser et al. (1984). If the Oostenbrink (1966) classification had been used, this cultivar would be classified as susceptible to the nematode. In our study by the Oostenbrink (1966) criteria all the cultivars are rated as susceptible, while by the Moura \& Régis (1987) criteria, there was a separation into groups: moderately resistant, low resistance, susceptible, and highly susceptible. In any case, no cultivar stood out for behaving as resistant or presentied an RF inhibition percentage above $90 \%$.

\section{M. javanica penetration and development in soybean cultivars under different inoculum con- centrations}

In the evaluation carried out ten days after inoculation it was observed the presence of second (J2) and third (J3) stage juveniles within the roots and significant differences were observed among the cultivars $(P<0.05)$. The statistical analysis revealed that there was no significant interaction between cultivars and inoculum concentrations $(P>0.05)$ (Table 2$)$.

The J2 penetration was greater in the roots of the cultivars UFU Carajás and NS 7476, which differed from the P98Y70 cultivar $(P<0.05)$. The latter equaled the cultivar BRSGO Paraíso, which was used as the standard for comparison, although its behavior is moderately resistant (Table 2 ). The quantity of $\mathrm{J} 2 /$ root system observed goes in the opposite direction to that described by Herman et al. (1991) and Moura et al. (1993), who by evaluating the $M$. incognita resistant (Forest) cultivar observed low values up to the $16^{\text {th }} \mathrm{DAl}$ and attributed this fact to the rate of emigration to the substrate from the fifth day after inoculation, while in the susceptible (Bossier) cultivar J2 penetration increased significantly.

With regards to the quantity of $\mathrm{J} 3$ found in the interior of the roots, it was observed that UFU Carajás and BRSGO Paraíso presented the lowest values $(\mathrm{P}<$ 0.05). The reduction in $\mathrm{J} 3$ development in the roots of these cultivars, compared to P98Y70 and NS 7476, may be due to the mechanism of resistance. According to Moura et al. (1993), by evaluating resistant soybean cultivars ten DAI with $M$. incognita, they noted that the root cells were disorganized and necrotic, and the formation of feeding sites did not occur.

An increase in the inoculum concentration caused a linear increasing effect on the number of $\mathrm{J} 2$ and $\mathrm{J} 3$ found in the roots (Figure 1). The number of J2 was greater than that of $\mathrm{J} 3$ in all of the concentrations used. In the concentration of 300 eggs/plant the presence of $9.83 \mathrm{~J} 2 /$ root system and $2.12 \mathrm{~J} 3 /$ root system was observed. As the inoculum concentrations increased, the numbers of $\mathrm{J} 2$ and $\mathrm{J} 3 /$ root system increased up to 87.50 and 11.04 , respectively (Table 2). Rocha et al. (2008) evaluated the amount of $M$. javanica J2 that had penetrated into the roots of cultivar Embrapa 20 (Doko RC) four days after inoculation and also observed an increasing number of J2/root system as the inoculum concentrations increased. 
Table 2 - Second (J2) and third (J3) stage juveniles per root system of four soy cultivars inoculated with different $M$. javanica inoculum concentrations at ten days after the inoculation.

\begin{tabular}{|c|c|c|c|c|c|}
\hline \multirow[t]{3}{*}{ Cultivar } & \multicolumn{5}{|c|}{ Inoculum concentration $^{1}$} \\
\hline & 300 & 600 & 1200 & 2400 & Mean \\
\hline & \multicolumn{5}{|c|}{$\mathrm{J} 2^{1}$} \\
\hline UFU Carajás & 7.33 & 5.83 & 29.16 & 58.66 & $25.25 \mathrm{a}^{2}$ \\
\hline BRSGO Paraíso & 8.66 & 20.66 & 61.50 & 110.16 & $50.25 \mathrm{bc}$ \\
\hline P98Y70 & 16.00 & 26.16 & 57.33 & 105.66 & $51.29 \mathrm{c}$ \\
\hline NS7476 & 7.33 & 14.83 & 32.00 & 76.50 & $32.66 \mathrm{ab}$ \\
\hline Mean & 9.83 & 16.87 & 45.00 & 87.50 & \\
\hline \multirow[t]{2}{*}{ CV (\%) } & \multicolumn{5}{|c|}{33.74} \\
\hline & \multicolumn{5}{|c|}{ J31 } \\
\hline UFU Carajás & 1.00 & 1.33 & 5.83 & 7.83 & $4.00 \mathrm{a}$ \\
\hline BRSGO Paraíso & 1.33 & 1.00 & 4.66 & 4.66 & $2.91 \mathrm{a}$ \\
\hline P98Y70 & 3.50 & 9.00 & 14.66 & 19.16 & $11.58 b$ \\
\hline NS7476 & 2.66 & 4.83 & 9.33 & 12.50 & $7.33 \mathrm{~b}$ \\
\hline Mean & 2.12 & 4.04 & 8.62 & 11.04 & \\
\hline CV (\%) & \multicolumn{5}{|c|}{40.33} \\
\hline
\end{tabular}

1- Data transformed into $\sqrt{ }(x+0.5)$ for statistical analysis.

2- Means followed by the same letter in the columns do not differ from each other (Tukey, $5 \%$ probability).

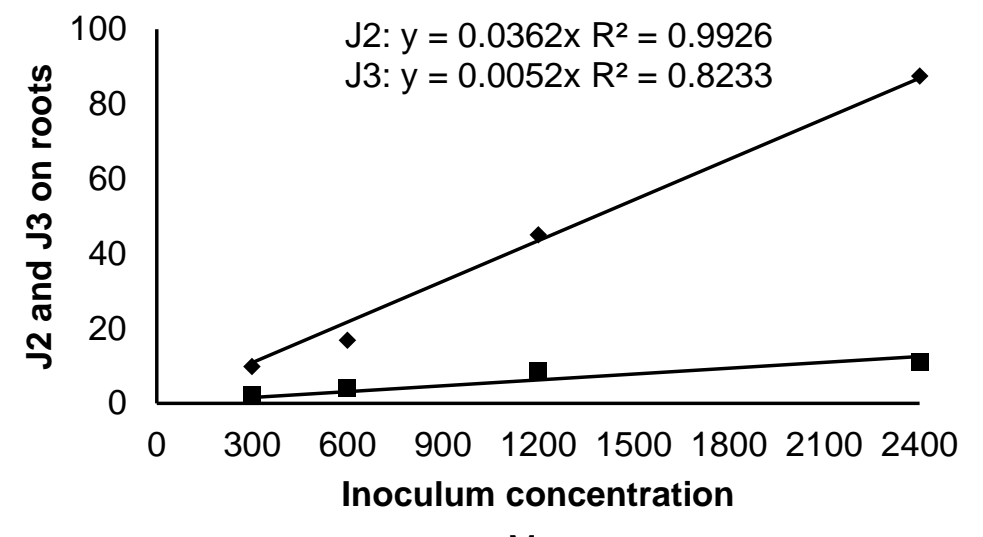

Mean

$\bullet$ J2 $\mathbf{J} 3$

Figure $1-M$. javanica $\mathrm{J} 2$ and $\mathrm{J} 3 /$ root system at 10 days after inoculation with different nematode concentrations in the four soybean cultivars.

The cultivar BRSGO Paraíso considered moderately resistant to $M$. javanica (Embrapa, 2011) had one of the highest J2/root system values; however, the amount of $\mathrm{J} 3 /$ root system was the lowest among the cultivars (Table 2). According to Carneiro et al. (2005), this reduction may be due to some resistance mechanism that acts after nematode penetration, interrupting the development cycle. Faria et al. (2003) observed that in resistant plants the accumulation of phytoalexins coincides with a hypersensitive reaction. Thus, phytoaxelins act as nematostatic drastically affecting nematode function and impeding their development.

In the final $M$. javanica population density evaluation there was a significant interaction between the cultivars and the inoculum concentrations. With the lowest inoculum concentration there was no difference
$(P>0.05)$ between the cultivars (Table 3$)$, but from inoculum concentrations of 600 eggs and J2/plant upwards a decrease in the population density was observed in cultivars UFU Carajás and BRSGO Paraíso, which is confirmed by the significant difference $(P<0.05)$ between these two cultivars and the rest for the highest concentration of 2400 eggs/plant.

Although $\mathrm{J} 2$ penetration in the roots did not show high differences among the cultivars, the number of $\mathrm{J} 3$ was lower in the cultivars UFU Carajás and BRSGO Paraíso (Table 2). The same trend was observed in the final population evaluation (Table 3), indicating that these two cultivars may have some degree of resistance.

The cultivars P98Y70 and NS 7476 reacted as more susceptible, as they presented a greater number of $\mathrm{J} 3$ in the roots (Table 2) and higher final population 
density (Table 3 ). Moreover, these two cultivars presented a linear increase in $M$. javanica population density in the roots, the more the inoculum concentrations were increased (Figure 2A and Figure 2B). The initial inoculum concentration influenced the final nematode population density, as populations with low initial levels increased exponentially for a short period of time, but due to competition for food sites or some other limitation imposed by the environment they presented a decrease in the growth rates. This was observed in Rocha et al. (2008) that used M. javanica inoculum concentrations varying from 0 to $300 \mathrm{~J} 2 /$ plant and found that the $\mathrm{J} 2$ and female $M$. javanica values inside the root were proportional to the initial inoculum. However, Asmus \& Ferraz (2001) testing inoculum concentrations varying from 0 to $97200 \mathrm{~J} 2 /$ plant observed reductions in the quantity of $M$. javanica eggs/gram of root at inoculum concentrations above $3600 \mathrm{~J} 2 /$ plant.

Table 3 - Population density (eggs and J2/10 $\mathrm{g}$ of root) of $M$. javanica in the roots of four soybean cultivars uncer different $M$. javanica inoculum concentrations at 45 days after inoculation.

\begin{tabular}{lccccr}
\hline \multirow{2}{*}{ Cultivar } & \multicolumn{5}{c}{ Inoculum concentration $^{1}$} \\
\cline { 2 - 6 } & 300 & 600 & 1200 & 2400 & Average \\
\hline UFU Carajás & $283.16 \mathrm{a}^{2}$ & $287.83 \mathrm{a}$ & $528.33 \mathrm{a}$ & $1383.50 \mathrm{a}$ & 620.70 \\
BRSGO Paraíso & $328.66 \mathrm{a}$ & $701.00 \mathrm{ab}$ & $704.83 \mathrm{ab}$ & $2031.50 \mathrm{a}$ & 941.50 \\
P98Y70 & $666.83 \mathrm{a}$ & $2869.83 \mathrm{c}$ & $2263.66 \mathrm{~b}$ & $9293.50 \mathrm{~b}$ & 3773.45 \\
NS7476 & $1164.00 \mathrm{a}$ & $2146.00 \mathrm{bc}$ & $1822.00 \mathrm{ab}$ & $6218.83 \mathrm{~b}$ & 2837.50 \\
\hline Average & 610.66 & 1501.16 & 1329.70 & 4731.83 \\
\hline CV (\%) & \multicolumn{5}{c}{43.85} \\
\hline
\end{tabular}

1. The data were transformed into $\sqrt{ }(x+0.5)$ for statistical analysis.

2- Averages followed by the same letter in the columns no not differ from each other (Tukey, $5 \%$ probability)

A

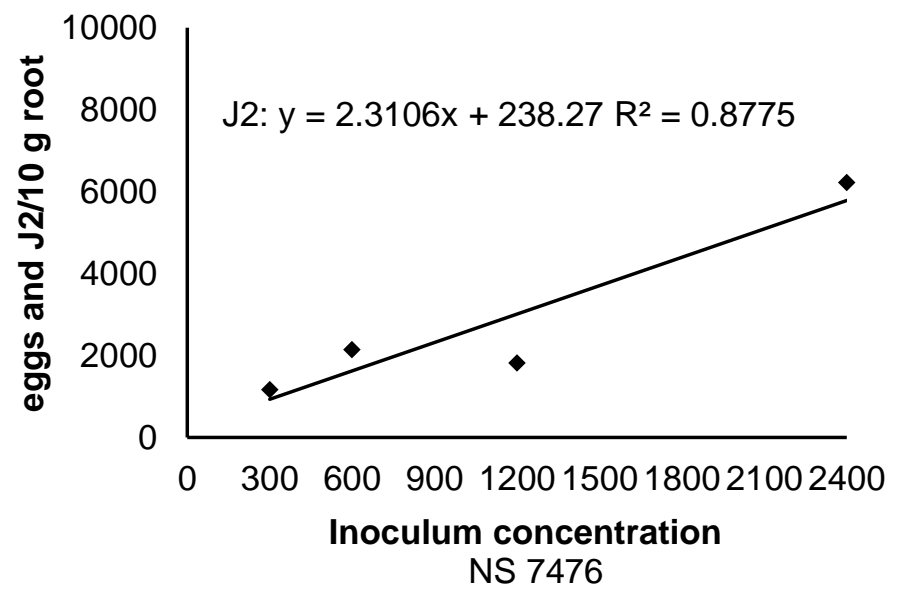

B

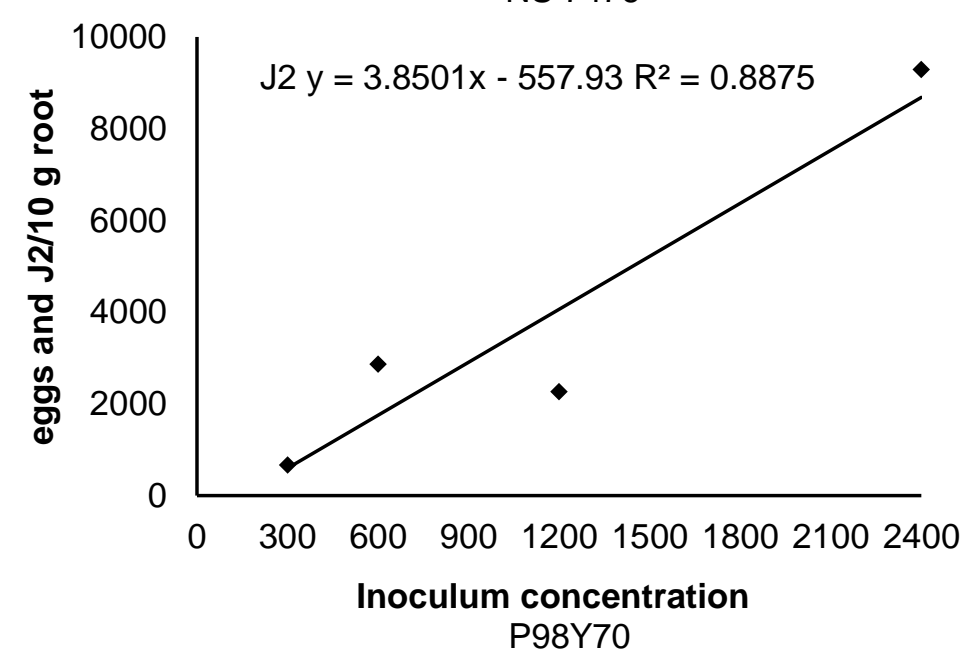

Figure 2 - $M$. javanica eggs and $\mathrm{J} 2 / 10 \mathrm{~g}$ of root at 45 days after inoculation with different nematode concentrations in the cultivars NS 7476 (A) and P98Y70 (B). 


\section{Conclusions}

No soybean cultivar, among those tested, react as resistant to Meloidogyne. javanica.

All soybean cultivars tested present RF greater than 1.0, but about 14 cultivars react as low (LR) or moderately (MR) resistant.

The cultivars UFU Carajás and BRSGO Paraíso present less $M$. javanica development in the roots compared with P98Y70 and NS 7476.

As the inoculum concentration increases the penetration and development of $M$. javanica in the soybean roots increases.

\section{References}

Agrianual (2014) Anuário da Agricultura Brasileira. Instituto FNP Consultoria \& Agrolnformativos, 480p.

Asmus GL, Ferraz LCCB (2001) Relações entre a densidade populacional de Meloidogyne javanica e a área foliar, a fotossíntese e os danos caudados a variedades de soja. Nematologia Brasileira 25(1):1-13.

Byrd DW, Kirkpatrick T, Barker KR (1983) An improved technique for clearing and staining plant tissues for detection of nematodes. Journal of Nematology 15(1):142-143.

Carneiro RMDG, Neves DI, Falcão R, Paes NS, Cia E, Sá MFG (2005) Resistência de genótipos de algodoeiro a Meloidogyne incognita Raça 3: Reprodução e Histopatologia. Nematologia Brasileiria 29(1):1-10.

Coolen WA, D'Herde CJ (1972) A method for the quantitative extraction of nematodes from plant tissue. State Nematology and Entomology Research Station. $77 p$.

Costa NL (2005) Complexo soja: Sua importância para o agronegócio, a balança comercial e a economia brasileira. Universidade Regional Integrada do Alto Uruguai e das Missões (Monografia de especialização em Comério Extrerior).

Dias WP, Freitas VM, Ribeiro NR, Moita AW, Homechin M, Parpinelli NMB, Carneiro MDG (2010) Reação de genótipos de soja Meloidogyne enterolobii e Meloidogyne ethiopica. Nematologia Brasileira 34(4):220-225.

Embrapa (2011) Tecnologia de produção de soja região central do Brasil 2012 e 2013. Embrapa Soja. $261 p$.

Faria CMDR, Salgado SML, Campos HD, Resende MLV, Campos VP, Coimbra JL (2003) Mecanismos de ataque e defesa na interação nematóide-planta. In.: Fernandes JM, Prestes AM, Picinini EC (ed) Revisão anual de patologia de plantas, RAPP. P.373-410.
Ferraz LCCB (2001) As Meloidoginoses da soja: passado, presente e futuro. In: Silva JFV (org) Relações parasito-hospedeiro nas meloidoginoses da soja. Embrapa Soja/Sociedade Brasileira de Nematologia. p.15-38.

Ferraz LCCB (2006) O nematóide Pratylenchus brachyurus e a soja sob plantio direto. Revista Plantio Direto 96:23-27.

Ferraz S, Mendes ML (1992) O nematóide das galhas. Informe Agropecuário 16(172):37-42.

Ferreira DF (2011) Sisvar: a computer statistical analysis system. Ciência e Agrotecnologia 35(6):1039-1042.

Herman M, Hussey RS, Boerma HR (1991) Penetration and development of Meloidogyne incognita on roots of resistant soybean genotype. Journal of Nematology 23(2):155-161.

Hooper D.J (1970) Handling, fixing, staining and mouting nematodes. In: Southey JF (ed) Laboratory methods with nematodes. Commovealth Agricultural. p.5-30.

Inomoto MM, Silva RA (2011) Importância dos nematóides da soja e influência da sucessão de cultura. Boletim de pesquisa da soja 2011 15(392-399).

Mendes ML, Rodriguez PBN (2000) Reação de cultivares de soja [Glycine max (L.) Merrill] aos nematóides de galhas Meloidogyne javanica e $M$. incognita raças 1, 2, 3 e 4. Nematologia Brasileira 24(2):211-217.

Miranda DM, Favoreto L, Ribeiro NR (2011) Nematóides - um desafio constante. Boletim de pesquisa da soja 2011 15:400-414.

Moritz MP, Carneiro RG, Santiago DC Nakamura KC, Pignoni E, Gomes JC (2008) Estudo comparativo da penetração e reprodução de Meloidogyne paranaensis em raízes de cultivares de soja resistente e suscetível. Nematologia Brasileira 32(1):33-40.

Moura R.M (1996) O Gênero Meloidogyne e a meloidoginose. Parte I. In: Luz WC, Fernandes JM, Prestes AM, Picinini EC (ed) Revisão Anual de Patologia de Plantas. RAPP. p.209-244.

Moura RM (1997) O Gênero Meloidogyne e a meloidoginose. Parte II. In: Luz WC, Fernandes JM, Prestes AM, Picinini EC (ed) Revisão Anual de Patologia de Plantas. RAPP. p.281-315.

Moura RM, Davis EL, Luzzi BM, Boerma HR, Hussey RS (1993) Post-infectional development of Meloidogyne incognita on susceptible and resistant soybean genotypes. Nematropica 23(1):7-13. 
Moura RM, Régis EMO (1987) Reação de cultivares de feijoeiro comum (Phaseolus vulgaris) em relação ao parasitismo de Meloidogyne javanica e $M$. incognita (Nematoda: Heteroderidae). Nematologia Brasileira 11(1):215-335.

Oostenbrink M (1966) Major characteristic of relation between nematodes and plants. Mededelingen Landbouwhogeschool 66(4):1-46.

Ramalho MAP, Ferreira DF, Oliveira AC (2000) Experimentação em genética e melhoramento de plantas. UFLA. 326p.

Rocha FS, Pinheiro JB, Campos HD, Campos VP (2008) Relação entre populações iniciais de Meloidogyne javanica e Heterodera glycines e do desenvolvimento do sistema radicular da soja. Nematologia Brasileira 32(2):161-166.
Sasser JN, Carter CC, Hartman KM (1984) Standardization of Host Suitability Studies and Reporting of Resistance to Root-knot nematodes. North Carolina State University Graphics. 7p.

Tihohod D, Ferraz S (1986) Variabilidade de três populações de Meloidogyne javanica em plantas de soja. Nematologia Brasileira 10:163-171.

Yorinori JT, Kiihl RAS (2001) Melhoramento de plantas visando resistência a doenças. In: Nass LL, Valois ACC, Melo IS, Valadares-Inglis MC (ed) Recursos genéticos e melhoramento - Plantas. Fundação MT. p.715-735. 